\title{
New update on molecular diversity of clinical Staphylococcus aureus isolates in Iran: Antimicrobial resistance, adhesion and virulence factors, biofilm formation and SCCmec typing
}

\section{Mahtab Tabandeh}

Department of Microbiology, Ayatollah Amoli Branch, Islamic Azad University, Amol

Hami Kaboosi ( $\nabla$ h.kaboosi@iauamol.ac.ir)

Department of Microbiology, Ayatollah Amoli Branch, Islamic Azad University, Amol https://orcid.org/00000002-3407-0950

\section{Mojtaba Taghizadeh Armaki}

Infection Diseases and Tropical Medicine Research Center, Babol University of Medical Sciences, Babol

\section{Abazar Pournajaf}

Department of Microbiology, School of Medicine, Babol University of Medical University, Babol

\section{Fatemeh Peyravii Ghadikolaii}

Department of Biology, Qaemshahr Branch, Islamic Azad University, Qaemshahr

\section{Research Article}

Keywords: Staphylococcus aureus, Virulence factor, Antibiotic resistance, Biofilm, SCCmec typing, Iran

Posted Date: May 11th, 2021

Dol: https://doi.org/10.21203/rs.3.rs-473636/v1

License: @ (i) This work is licensed under a Creative Commons Attribution 4.0 International License. Read Full License

Version of Record: A version of this preprint was published at Molecular Biology Reports on January 21st, 2022. See the published version at https://doi.org/10.1007/s11033-022-07140-7. 


\section{Abstract}

Staphylococcus. aureus is often considered as a potential pathogen and resistant to a wide range of antibiotics. The pathogenicity of this bacterium is due to the presence of multiple virulence factors and ability to form biofilm. SCCmec types I, II and III are mainly attributed to HA-MRSA, while SCCmec types IV and V have usually been reported in CA-MRSA infections. In this study, we performed a cross-sectional study in order to determine the antimicrobial resistance, adhesion and virulence factors, biofilm formation and SCCmectyping of clinical $S$. aureus isolates in Iran. $S$. aureus isolate was identified using microbiological standard methods and antibiotic susceptibility test was performed as described by the Clinical and Laboratory Standards Institute (CLSI) guidelines. Inducible resistance phenotype and biofilm formation were determined using D-test and tissue culture plate methods, respectively. Multiplex-PCRs were performed to detect adhesion and virulence factors, antibiotic resistance genes, biofilm formation and SCCmectyping by specific primers. Among 143 clinical samples, $67.8 \%$ were identified as MRSA. All isolates were susceptible to vancomycin. The prevalence of $\mathrm{cMLS}_{B}$, iMLS $\mathrm{B}_{\mathrm{B}}$ and MS phenotypes were $61.1 \%, 22.2 \%$ and $14.8 \%$, respectively. The TCP method revealed that $71.3 \%$ of isolates were able to form biofilm. The predominant virulence and inducible resistance genes in both MRSA and MSSA isolates were related to sea and ermC respectively. SCCmec type III was the predominant type. Data show the high prevalence rates of virulence elements among $S$. aureus isolates, especially MRSA strains. This result might be attributed to antibiotic pressure, facilitating clonal selection.

\section{Introduction}

Staphylococcus aureus ( $S$. aureus) is one of the most common cause of health-care and community acquired infections and so responsible for a wide variety of illnesses, from soft and skin tissue infections (SSTIs) to lifethreatening infections such as septicemia, toxic shock, hospital- and community- acquired pneumonia (HAP and CAP) and endocarditis [1]. S. aureus clinical isolates often promote infections by expressing of various exotoxins such as heat-stable staphylococcal enterotoxins (SEs), staphylokinase (SAK), toxic shock syndrome toxin-1 (TSST-1), capsular polysaccharides, lipase, exfoliative toxins (ETA and ETB), hemolysins ( $a, \beta, \gamma, \delta)$ and leukocidins (Panton-Valentine leukocidin; PVL, LukE/D) [2]. From the clinical point of view, indwelling medical devices or catheter-related infections such as central venous catheters (CVC), are at risk of $S$. aureus related infection. The ability to form a stable biofilms is one of the most crucial factors in $S$. aureus pathogenicity and biofilm-associated $S$. aureus infections are often resistant to antibiotic therapy and innate host immune system [3]. Biofilm formation requires polysaccharide intercellular adhesin (PIA), which is encoded and regulated by the intercellular adhesion (icaADCB) operon. This operon includes an $\mathrm{N}$-acetylglucosamine transferase (icaA and icaB), a predicted exporter (icaC), and a deacetylase (icaD) [1, 4].

Multidrug-resistant $S$. aureus (MDRSA), is becoming a serious global concern, as a commen cause of nosocomial- and community acquired infections [5]. In recent years, methicillin-resistant $S$. aureus (MRSA), which is now the most common MDR, have emerged with the acquisition of Staphylococcal Cassette Chromosome mec (SCCmec) elements, which carry a mecA gene that encodes a penicillin binding protein (PBP2a or PBP2区) with a low affinity to $\beta$-lactams [6]. MRSA are spread worldwide and are common causes of health care (HAls)-and community-acquired (CAls) infections. SCCmec determinants are classified into various types based on the combination of $c c r$ and mec genes complexes, which includes 5 and $8 m e c$ and $c c r$ classes, respectively. To date, at least 13 types of SCCmec elements have been recognized and all SCCmectypes have individual 
characteristics. In general, SCCmec type I, II, and III are distributed in the hospital-associated MRSA (HA-MRSA) and type IV and V are present in the community-acquired MRSA (CA-MRSA) [7].

The Mupirocin -a topical ointment that broadly used for SSTIs and nasal decolonization of MRSA-is effective on the isoleucyl-tRNA synthetase (lleRS) which is encodes by ileS gene, interfering with protein synthesis. According to the minimal inhibitory concentration (MIC), two mupirocin-resistant phenotypes have been identified; MIC 8$256 \mu \mathrm{g} / \mathrm{ml}$ (low-level resistant-LLR or LMR) and MIC $\geq 512 \mu \mathrm{g} / \mathrm{ml}$ (high-level resistant-HLR or HMR). A point mutation in ileS-1 gene (mupL) led to LLR isolates, while HLR usually mediated by a conjugate plasmid-borne ileS-2 (mupA) gene which encodes a new lleRS that is not bound by mupirocin [8]. Aminoglycosides are a class of bactericidal broad spectrum antimicrobials that bind to the A-position of 16S rRNA in 30S ribosomal small subunit and inhibit protein synthesis. Aminoglycoside-modifying enzymes (AMEs) and 16S ribosomal RNA (16S rRNA) methylation are two important mechanisms for antibiotic inactivation in the $S$. aureus [9]. Based on their functions, AMEs are generally categorized to three types: AAC (aminoglycoside acetyltransferase), APS (aminoglycoside phosphotransferase), and ANT (aminoglycoside nucleotidyltransferase). Numerous AMEs, counting variants of acetyltransferases $\mathrm{AAC}(3)-\mathrm{I}, \mathrm{AAC}(3)-\mathrm{II}, \mathrm{AAC}(3)-\mathrm{III}, \mathrm{AAC}\left(6^{\prime}\right)-\mathrm{I}, \mathrm{AAC}\left(6^{\prime}\right)-\mathrm{II}$, and $\mathrm{AAC}\left(6^{\prime}\right)-\mathrm{III}$, the phosphotransferases $\mathrm{APH}\left(3^{\prime}\right)-\mathrm{I}, \mathrm{APH}\left(3^{\prime}\right)-\mathrm{II}$, and $\mathrm{APH}\left(3^{\prime}\right)-\mathrm{VI}$, and the nucleotidyltransferases ANT(3)-I, ANT(4')-I, and ANT(2")-I have been known so far in $S$. aureus $[10,11]$.

The aim of this study was new update on molecular diversity of antimicrobial resistance, adhesion and virulence factors, biofilm formation and SCCmec typing of clinical S. aureus isolates in Iran.

\section{Material And Methods}

\section{Clinical sampling and laboratory identification}

A total of 143 non-duplicative clinical samples were collected from admission patient referred to teaching therapeutic hospitals (Shahid Beheshti \& Ruhani Hospitals, Babol, Iran) in a period of 8 months from September 2019 to April 2020. The samples were transported to the microbiology laboratory in Brain-Heart Infusion Broth (Merck Co., Germany). Each sample was cultured on Mannitol Salt Agar (supplemented with 7.5\% sodium chloride) (Merck Co., Germany) and incubated in $37^{\circ} \mathrm{C}$ for $24 \mathrm{~h}$. All S. aureus colonies were identified based on routine biochemical and microbiological standard tests [12].

\section{Antimicrobial susceptibility test}

Antimicrobial susceptibility was determined using the agar disk diffusion method on Mueller-Hinton agar plates (Merck Co., Germany) as described by the Clinical and Laboratory Standards Institute (CLSI document M100-S14) [13]. The test antimicrobials were used as follows; Clindamycin (CD; $2 \mu \mathrm{g})$, Erythromycin (ERY; $15 \mu \mathrm{g}$ ), Gentamicin $(\mathrm{GM} ; 10 \mu \mathrm{g})$, Vancomycin (VAN; $30 \mu \mathrm{g})$, Ciprofloxacin (CIP; $5 \mu \mathrm{g})$, Tetracycline (TET; $30 \mu \mathrm{g})$, Mupirocin (MUP; $5 \mu \mathrm{g})$, Rifampicin (RIF; $2 \mu \mathrm{g}$ ), Cefoxitin (FOX; $30 \mu \mathrm{g}$ ), and Co-trimoxazole (SXT; $5 \mu \mathrm{g}$ ) (MAST Diagnostics, Merseyside, UK). Mupirocin MIC was determined by the E-test strip method (AB Biodisk, Solna, Sweden) on the Mueller-Hinton agar Petri dish according to the manufacturers' guidelines. S. aureus ATCC 29213 was used as positive quality control.

\section{Inducible resistance phenotype}


The Inducible resistance phenotype was recognized using the double disk test including, Clindamycin (CD; $2 \mu \mathrm{g})$ and Erythromycin (ERY; $15 \mu \mathrm{g}$ ) disks applied $20 \mathrm{~mm}$ separately [10,11]. After an incubation time of $24 \mathrm{~h}$ at $35^{\circ} \mathrm{C}$, a flattening inhibition zone adjacent to the ERY disk representing an inducible type (D-shaped zone) of $M L S_{B}$ resistance (IR), whereas no-susceptibility to both ERY and CD was mentioned to as a constitutive type (CR). The nonappearances of a D-shaped zone in ERY-resistant and CD-susceptible isolates were interpreted as the $M / \mathrm{MS}_{\mathrm{B}}$ efflux phenotype [14].

\section{Quantitative biofilm production assay}

In Brief, pure colonies were inoculated in $10 \mathrm{~mL}$ of $1 \%$ glucose-rich tryptic soy broth (TSBglu), incubated at $37^{\circ} \mathrm{C}$ for $24 \mathrm{~h}$ in stationary growth phase and diluted 1:100 with fresh medium. Each well of sterile 96 well-flat bottom polystyrene tissue culture microtiter plates (Falcon® 3046, Lincoln Park, NJ) was full with $200 \mu$ l aliquots of diluted cultures. Sterile TSBglu broth was used as a negative control. All plates were incubated at $37^{\circ} \mathrm{C}$ for $24 \mathrm{~h}$ and then, substances of all wells were gradually removed by tapping the petri. The wells were washed three times with $0.3 \mathrm{~mL}$ of phosphate buffer saline (PBS, pH 7.2) to remove loosely attached and floating "planktonic" microorganisms. Biofilm formed by adherent "sessile" isolates in petri were immobile with sodium acetate (NaA) and stained with crystal violet $(0.1 \% \mathrm{w} / \mathrm{v})$. Extra dye was removed by washing with sterile dideionized water and plates were kept for drying. Adherent $S$. aureus cells frequently formed biofilm on the sides of the wells and were regularly stained with crystal violet (CV; $1 \%)$. The investigation of biofilm formation was assessed by adding the $200 \mu$ of $95 \% \mathrm{CH} \rrbracket-\mathrm{CH} \rrbracket-\mathrm{OH}$ (ethanol) to decolorize the wells. Optical density (OD) of stained adherent isolates were measured with a micro ELISA auto-reader (Bio-Tek Instruments, USA) at wavelength of $570 \mathrm{~nm}$ (OD570 nm). Biofilm formation was recorded as follows: non-biofilm forming (A570<1); weak $(1<\mathrm{A} 570<2)$; ++ , moderate $(2$ $<$ A570 < 3); +++, strong $($ A570 >3) $[1,15]$.

\section{Multiplex-Polymerase Chain Reactions (M-PCRs)}

M-PCRs reactions were performed for detection of virulence, resistance and biofilm corresponding genes. Chromosomal DNA was extracted from the pure colonies using the Bacterial Genomic DNA Extraction kit (TaKaRa Biotechnology Co., Ltd, Dalien, China). The DNA concentration and purity were evaluated using a Nanodrop ND-1000 spectrophotometer (Thermo Fisher Scientific, UK) and then kept at -20 ${ }^{\circ} \mathrm{C}$ until further use. The details of the primers used in this study are shown in Table 1. The process of M-PCR reactions in the final volume of $25 \mu$ was performed according to Table 2 in an Eppendorf MasterCycle Gradient Thermocycler (Eppendorf, Hamburg, Germany). M-PCRs products were electrophoresed in a $1 \%$ agarose/0.5 × TBE (45 mM-Tris-borate, $1 \mathrm{mM}$-EDTA) gel stained with $0.1 \mu \mathrm{l} / \mathrm{ml} \mathrm{Gel} \mathrm{Red}^{\text {TM }}$ (Biotium, USA), then photographed under an UV trans-illuminator (Tanon, China).

\section{Data analysis}

SPSS version 18.0 for Windows (SPSS Inc., Chicago, USA) was used for statistical analysis. $P \leq 0.05$ was considered as a statistical significance.

\section{Results}

In this cross-sectional study, clinical samples were collected from 143 patients, $51.7 \%(n=74)$ female and $48.3 \%$ $(n=96)$ male with the mean age of $61.4 \pm 1.1$ years (range from 14 to 98 years). $S$. aureus isolates were collected 
from several clinical samples including, wound $(n=38,26.6 \%)$, pus $(n=31 ; 21.7 \%)$, blood $(n=27 ; 18.9 \%)$, skin lesion $(n=19 ; 13.3 \%)$, bronchoalveolar lavage $(n=11 ; 7.7 \%)$, sputum $(n=9 ; 6.3 \%)$, intratracheal tube $(n=6 ; 4.2 \%)$, joint fluid ( $n=1 ; 0.7 \%)$, and cerebrospinal fluid (CSF) $(n=1 ; 0.7 \%)$. The majority of $S$. aureus was isolated from different wards of the hospital as follows: ICU ( $n=38 ; 26.6 \%)$, NICU ( $n=26 ; 18.2 \%)$, internal medicine $(n=19$; $13.3 \%)$, surgery $(n=15 ; 10.5 \%)$, urology $(n=14 ; 9.9 \%)$, hemodialysis $(n=14 ; 9.9 \%)$, ENT (Ear, Nose and Throat) ( $n$ $=7 ; 4.9 \%)$ hematology-oncology $(n=6 ; 4.2 \%)$, gynecology $(n=2 ; 1.4 \%)$, neurosurgery $(n=1 ; 0.7 \%)$ and orthopedics $(n=1 ; 0.7 \%)$. Of the $143 \mathrm{~S}$. aureus strains, $67.8 \%(n=97)$ were resistant to $30 \mu \mathrm{g}$-FOX disk phenotypically considered as MRSA isolates and confirmed by mecA-gene amplification using PCR. As shown in Table 3, the resistance rate in MRSA strains was higher than MSSA (P-value $\leq 0.05$ ) (Table 3). The resistance rate on MRSA strains showed that $91.7 \%, 87.6 \%, 84.5 \%, 83.5 \%, 76.3 \%, 62.8 \%, 55.7 \%$ and $31.9 \%$ of isolates were resistant to CIP, GM, SXT, ERY, TET, RIF, CD and MUP, respectively. MUP MIC E-test showed that, of 31 MUP-resistant MRSA strains, $16.1 \%(n=5)$ and $83.9 \%(n=26)$ were MuL and MuR respectively. Also, all MSSA isolates were susceptible to RIF and MUP. Among the $143 \mathrm{~S}$. aureus isolates, 78.3\% $(n=112)$ of the isolates were resistant to at least 3 different antibiotic classes and therefore considered as MDR. The frequency of MDR strains in MRSA and MSSA isolates was $75.3 \%(n=73 / 97)$ and $45.6 \%(n=21 / 46)$, respectively. The result of inducible resistance test showed that $39.2 \%(n=56)$ of the isolates were resistant to both CD and ERY. Indeed, $61.1 \%(n=33)$ strains had resistant phenotype to $\mathrm{CMLS}_{\mathrm{B}}$ (resistant to both ERY and CD), 22.2\% $(n=12)$ were inducible resistance iMLS (resistant to $_{\mathrm{B}}$ ERY but susceptible to CD), $14.8 \%(n=8)$ isolates had the MS phenotype (susceptible to ERY and resistant to CD) and lastly, 5.5\% $(n=3)$ were susceptible to ERY and resistant to CD. All iMLS $S_{B}$ strains, except two isolates, belonged to the MRSA. The prevalence of $\mathrm{CMLS}_{B}, \mathrm{iMLS}_{\mathrm{B}}$ and MS phenotypes in the MRSA isolates were $81.8 \%$ ( $\mathrm{n}$ $=27), 83.3 \%(n=10)$ and $62.5 \%(n=5)$, respectively. So, $11.1 \%(n=6), 3.7 \%(n=2)$ and $5.5 \%(n=3)$ of MSSA isolates have $\mathrm{CMLS}_{\mathrm{B}}$, iMLS $\mathrm{B}$ and MS phenotypes, respectively. The TCP method revealed that $71.3 \%(\mathrm{n}=$ $102 / 143)$ of isolates were able to form biofilm, including strong $(n=69 / 102,67.6 \%)$, moderate $(n=21 / 102$, $20.6 \%$ ) and weak $(n=12 / 102,11.7 \%)$. Blood and wound isolates have the highest proportion for strong biofilm phenotype $(n=21 / 27 ; 77.7 \%$, and $n=27 / 38 ; 71.1 \%)$. Biofilm formation in MRSA isolates was far greater than MSSA (P value $\leq 0.05)$. In MRSA isolates, 84.1\% ( $n=58 / 69), 80.9 \%(n=17 / 21)$ and $58.3 \%(n=7 / 12)$ of isolates had a strong, moderate and weak phenotype, respectively. But, in the MSSA strains $84.1 \%(n=11 / 69), 19 \%(n=$ $4 / 21)$ and $41.6 \%(n=5 / 12)$ had strong, moderate and weak biofilm formation phenotype, respectively. 
Table 3

Antimicrobial resistance profile in MRSA and MSSA strains

\begin{tabular}{|c|c|c|c|c|c|c|c|c|c|c|}
\hline \multicolumn{2}{|c|}{ S. aureus isolates } & \multicolumn{9}{|c|}{ No, $(\%)$ of antimicrobial resistance pattern } \\
\hline & & ERY & CD & GM & CIP & TET & MUP & RIF & SXT & VAN \\
\hline \multirow[t]{3}{*}{$\begin{array}{l}\text { MRSA (n=97, } \\
67.8 \%)\end{array}$} & S & $\begin{array}{l}16 \\
(16.5)\end{array}$ & $\begin{array}{l}42 \\
(43.3)\end{array}$ & $\begin{array}{l}12 \\
(12.4)\end{array}$ & $\begin{array}{l}7 \\
(7.2)\end{array}$ & $\begin{array}{l}23 \\
(23.7)\end{array}$ & $\begin{array}{l}83 \\
(85.6)\end{array}$ & $\begin{array}{l}36 \\
(37.1)\end{array}$ & $\begin{array}{l}15 \\
(15.5)\end{array}$ & $\begin{array}{l}97 \\
(100 \%)\end{array}$ \\
\hline & 1 & $\begin{array}{l}0 \\
(0.0)\end{array}$ & $1(1)$ & $\begin{array}{l}0 \\
(0.0)\end{array}$ & $1(1)$ & $\begin{array}{l}0 \\
(0.0)\end{array}$ & $\begin{array}{l}0 \\
(0.0)\end{array}$ & $\begin{array}{l}0 \\
(0.0)\end{array}$ & $\begin{array}{l}0 \\
(0.0)\end{array}$ & $0(0.0)$ \\
\hline & $\mathrm{R}$ & $\begin{array}{l}81 \\
(83.5)\end{array}$ & $\begin{array}{l}54 \\
(55.7)\end{array}$ & $\begin{array}{l}85 \\
(87.6)\end{array}$ & $\begin{array}{l}89 \\
(91.7)\end{array}$ & $\begin{array}{l}74 \\
(76.3)\end{array}$ & $\begin{array}{l}14 \\
(14.4)\end{array}$ & $\begin{array}{l}61 \\
(62.8)\end{array}$ & $\begin{array}{l}82 \\
(84.5)\end{array}$ & $0(0.0)$ \\
\hline \multirow[t]{3}{*}{$\begin{array}{l}\text { MSSA (n= 46, } \\
32.2 \%)\end{array}$} & S & $\begin{array}{l}19 \\
(41.3)\end{array}$ & $\begin{array}{l}13 \\
(28.3)\end{array}$ & $\begin{array}{l}33 \\
(71.7)\end{array}$ & $\begin{array}{l}36 \\
(78.3)\end{array}$ & $\begin{array}{l}29 \\
(63)\end{array}$ & $\begin{array}{l}46 \\
(100)\end{array}$ & $\begin{array}{l}46 \\
(100)\end{array}$ & $\begin{array}{l}40 \\
(86.9)\end{array}$ & $\begin{array}{l}46 \\
(100 \%)\end{array}$ \\
\hline & 1 & $\begin{array}{l}0 \\
(0.0)\end{array}$ & $\begin{array}{l}1 \\
(2.2)\end{array}$ & $\begin{array}{l}0 \\
(0.0)\end{array}$ & $\begin{array}{l}1 \\
(2.2)\end{array}$ & $\begin{array}{l}2 \\
(4.3)\end{array}$ & $\begin{array}{l}0 \\
(0.0)\end{array}$ & $\begin{array}{l}0 \\
(0.0)\end{array}$ & $\begin{array}{l}0 \\
(0.0)\end{array}$ & $0(0.0)$ \\
\hline & $\mathrm{R}$ & $\begin{array}{l}27 \\
(58.7)\end{array}$ & $\begin{array}{l}32 \\
(69.6)\end{array}$ & $\begin{array}{l}13 \\
(28.3)\end{array}$ & $\begin{array}{l}9 \\
(19.6)\end{array}$ & $\begin{array}{l}15 \\
(32.6)\end{array}$ & $\begin{array}{l}0 \\
(0.0)\end{array}$ & $\begin{array}{l}0 \\
(0.0)\end{array}$ & $6(13)$ & $0(0.0)$ \\
\hline
\end{tabular}

Molecular distribution of virulence-related genes was significantly higher in MRSA strains, especially in the isolates collected from ICU (P-value $\leq 0.05$ ). The most prevalent virulence-related gene was sea in both MRSA and MSSA isolates. tsst-1, sec and sed genes were present only in MRSA strains. $8.2 \%$ and $2.3 \%$ of MRSA and MSSA isolates were positive for $p v /$ gene, respectively. The frequencies of inducible-resistance encoding genes in the MRSA strains were $21.6 \%, 16.5 \%, 44.3 \%$ and $9.3 \%$, respectively. Such as MRSA strains, in MSSA isolates ermC was the predominant gene. vanA gene was not detected in both MRSA and MSSA isolates. So, distribution of AMEs genes in MRSA strains were 33\%, 62.8\%, 24.7\% and 85.6\% for $A P H\left(3^{\prime}\right)-I, A P H\left(3^{\prime}\right)-I I l a, \operatorname{aac}\left(6^{\prime}\right) / \operatorname{aph}\left(2^{\prime \prime}\right)$ and ANT(4')-la, respectively. All MRSA biofilm-producing isolates carried the icaA gene. The prevalence of the ica genes in the MRSA strains was as follows: icaB (70.1\%), icaC (74.2\%) and icaD (81.4\%). Of 97 MRSA isolates, $55.7 \%(n=54)$ and $44.3 \%(n=43)$ were HA-MRSA and CA-MRSA, respectively. SCCmec type III was the most predominant type. In general, among 97 MRSA isolates, 34\% ( $n=33), 23.7 \%(n=23), 18.5 \%(n=18), 11.3 \%(n=$ 11) and $6.2 \%(n=6)$ were belonged to the SCCmec type III, I, IV, II, and V, respectively; though, $6.4 \%(n=6)$ isolates were nontypable. SCCmec type I was only found in the blood strains, types IV and V were mostly observed from wound, BAL and sputum and type III was found in all clinical samples (Table 4). 
Table 4

Distribution of virulence, resistance and biofilm genes in MRSA and MSSA isolates

\begin{tabular}{|c|c|c|c|}
\hline Gene type & gene & MRSA (n = 97) & $\operatorname{MSSA}(n=46)$ \\
\hline \multirow[t]{19}{*}{ virulence-related genes } & cna & $51(52.3 \%)$ & $28(60.7 \%)$ \\
\hline & clfA & $55(56.7 \%)$ & $19(41.3 \%)$ \\
\hline & $c / f B$ & $64(66 \%)$ & $31(67.4 \%)$ \\
\hline & $f n b A$ & $15(15.5 \%)$ & $17(37 \%)$ \\
\hline & $f n b B$ & $13(13.4 \%)$ & $21(45.7 \%)$ \\
\hline & $f i b$ & $73(75.3 \%)$ & $25(54.3 \%)$ \\
\hline & eno & $82(84.5 \%)$ & $33(71.3 \%)$ \\
\hline & hla & $88(90.7 \%)$ & $39(84.7 \%)$ \\
\hline & $h / b$ & $43(44.3 \%)$ & $6(13 \%)$ \\
\hline & hld & $80(82.5 \%)$ & $39(84.7 \%)$ \\
\hline & $h / g$ & $6(6.2 \%)$ & $13(28.3 \%)$ \\
\hline & tsst-1 & $5(5.2 \%)$ & $0(0.0 \%)$ \\
\hline & $P v l$ & $8(8.2 \%)$ & $1(2.3 \%)$ \\
\hline & sea & $97(100 \%)$ & $41(89.1 \%)$ \\
\hline & seb & $17(17.5 \%)$ & $2(4.3 \%)$ \\
\hline & $\sec$ & $5(5.2 \%)$ & $0(0.0 \%)$ \\
\hline & sed & $3(3.1 \%)$ & $0(0.0 \%)$ \\
\hline & eta & $11(11.3 \%)$ & $2(4.3 \%)$ \\
\hline & $e t b$ & $6(6.2 \%)$ & $4(6.5 \%)$ \\
\hline \multirow[t]{10}{*}{ Resistance encoding genes } & iles-2 & $8(8.2 \%)$ & $0(0.0 \%)$ \\
\hline & $A P H\left(3^{\prime}\right)-I$ & $32(33 \%)$ & $17(36.9 \%)$ \\
\hline & $A P H\left(3^{\prime}\right)-I I I a$ & $61(62.8 \%)$ & $21(45.6 \%)$ \\
\hline & $\operatorname{aac}\left(6^{\prime}\right) / \operatorname{aph}\left(2^{\prime \prime}\right)$ & $24(24.7 \%)$ & $6(13 \%)$ \\
\hline & $A N T\left(4^{\prime}\right)-1 a$ & 83 (85.6\%) & $12(26.1 \%)$ \\
\hline & $\operatorname{van} A$ & $0(0.0 \%)$ & $0(0.0 \%)$ \\
\hline & ermA & $21(21.6 \%)$ & $12(26.1 \%)$ \\
\hline & ermB & $16(16.5 \%)$ & $7(15.2 \%)$ \\
\hline & ermC & $43(44.3 \%)$ & $23(50 \%)$ \\
\hline & ereA & $9(9.3 \%)$ & $0(0.0 \%)$ \\
\hline
\end{tabular}




\begin{tabular}{|llll|}
\hline Gene type & gene & MRSA $(\mathbf{n}=\mathbf{9 7})$ & MSSA $(\mathbf{n}=\mathbf{4 6})$ \\
\hline Biofilm genes & $i c a A$ & $82(84.5 \%)$ & $36(78.3 \%)$ \\
\hline$i c a B$ & $68(70.1 \%)$ & $12(26.1 \%)$ \\
\hline$i c a C$ & $72(74.2 \%)$ & $18(39.1 \%)$ \\
\hline$i c a D$ & $79(81.4 \%)$ & $42(91.3 \%)$ \\
\hline
\end{tabular}

\section{Discussion}

In the current study, a high prevalence of MRSA (67.3\%) was found, especially in samples obtained from ICU and NICU wards. These data are in agreement with Mir et al (2019) [16], but do not agree with Darban-Sarokhalil et al (2016) [30]. In a study directed by Kateete et al (2011), all isolates were found to be MRSA [31]. These conflicts could be attributed to the sample types (burn vs. other samples), year of study, geographic location (Uganda vs Iran), level of hygiene, different protocols in infection control, irrational antibiotic administration, and laboratory method for determination of methicillin-resistant isolates. In line with our study, Guardabassi et al (2007) indicated that the $30 \mu \mathrm{g}$ Fox disk diffusion method is preferred to most of the other recommended tests such as; oxacillin disc diffusion and oxacillin screen agar tests and it is currently an accepted method for recognition of MRSA isolates by Clinical and Laboratory Standards Institute strategies [32].

The resistance rate in MRSA isolates is significantly higher than in the MSSA $(P \leq 0.05)$, which is consistent with the study of Solgi et al, (2019) [33], Mir et al (2019) [16] and Pournajaf et al (2014) [24]. Among antibiotics used for MRSA strains, CIP showed the least anti-staphylococcal activity and VAN was the most effective. According to the study performed by Solgi et al (2019) [33], VAN is still the best option in the treatment of patients with MRSA infection. In compare with other studies, there has been an increase in resistance to antimicrobial in MRSA isolates. The resistance rates in the MRSA straits were as follows: CIP (91.7\%), GM (87.6\%), SXT (84.5\%), ERY (83.5\%), TET (76.3\%), RIF (62.8\%), CD (55.7\%) and VAN (0.0\%). So, $78.3 \%$ of our isolates were considered MDR. This could be due to the continuous and empirical usage of broad-spectrum antimicrobials and the lack of an appropriate antibiotic treatment strategy. According to our data, although $14.4 \%$ of MRSA strains were resistant to MUP, it's still recommended as an option in the removal of MSSA nasal colonization. These data are in agreement with Chaturvedi et al (2014) [34] and Antonov et al (2015) [35] studies. Interestingly, among 14.4\% MUP-resistant MRSA strains, only $8.2 \%$ were positive for ileS-2 gene. These data are consistent with Solgi et al (2019) [33] and McNeil et al (2011) [36] studies. Solgi et al (2019) [33] declare that low-level MUP resistance may be occurred due to another responsible genes such as; mupL/D/W/O/T. Contrary to our study, Mir et al (2019) [16], showed that $85.6 \%$ of the isolates were resistant to MUP. On the other hand, Chen et al (2012) reported high frequency of MUP-resistant MRSA isolates in burn centers [37]. This topical bacteriostatic antimicrobial mainly used for prophylaxis against $S$. aureus nasal carriage and other skin diseases. Its target is the bacterial isoleucyl transfer ribonucleic acid synthetase. The long-term use of MUP, mostly for decolonization of nasal carriage, burn, diabetic foot, bedsores and other skin lesions could be related to development of resistance to MUP [33].

D-test revealed that the prevalence of CMLSB, iMLSB and MS resistance phenotypes were $61.1 \%, 22.2 \%$ and $14.8 \%$, respectively. This data has also been described by Solgi et al (2019) [33], Khodabandeh et al (2019) [14] and Gupta et al (2009) [38], but have conflict with Seifi et al (2012) [39], Adhikari et al (2017) [11], Ruiz-Ripa et al (2019) [40] and Deotale et al (2010) [10] studies. These conflicts may be related to year of study, topographical 
locations and surveillance strategies, as well as limitation in drug prescription. The rate of inducible resistance varies from hospital to hospital and even from patient to patient. In agreement with Solgi et al (2019) [33], and Gupta et al (2009) [38], the frequency of $\mathrm{CMLS}_{\mathrm{B}}$ phenotype was higher than iMLS ${ }_{\mathrm{B}}$, but in another study, the frequency of $i M L S_{B}$ phenotype showed to be higher than $c M L S_{B}$. Therefore, notice of regional frequency of $M_{L S} S_{B}$ resistant isolates is very important for microbiology laboratories to choose to perform D-test regularly. In concordance with Khodabandeh et al (2019) [14], ermC was the predominant gene on both MRSA and MSSA isolates. The prevalence of ermA, ermB, ermC and ereA in the MRSA isolates were $21.6 \%, 16.5 \%, 44.3 \%$ and $9.3 \%$, respectively. ereA gene was only found in the MRSA isolates which were collected from ICU. The combination of ermA/ ermB/ermC genes was detected in only two MRSA isolates collected from blood samples. So, $26.1 \%$, $15.2 \%$ and $23 \%$ of MSSA isolates were positive for ermA, ermB and ermC, respectively. Our findings contradicts with the study conducted by Ghanbari et al (2016) [41] and Saribas et al (2006) [42]. This discrepancy could be due to genetic variation and spread of single clone in our area. Distribution of AMEs genes in our samples were

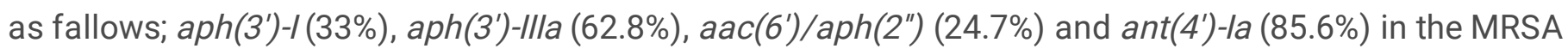

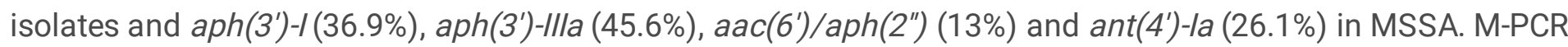
showed that $8.2 \%(n=8 / 97), 12.4 \%(n=12 / 97)$, and $33 \%(n=32 / 97)$ of MRSA isolates carried simultaneously $\operatorname{aph}\left(3^{\prime}\right)-I I I a / \operatorname{aac}\left(6^{\prime}\right) / \operatorname{aph}\left(2^{\prime \prime}\right), \operatorname{aph}\left(3^{\prime}\right)-I / \operatorname{aph}\left(3^{\prime}\right)-I I I a$, and $\operatorname{aph}\left(3^{\prime}\right)-I I I a / \operatorname{ant}\left(4^{\prime}\right)-$ la genes, respectively. Only $2.1 \%(\mathrm{n}=$ 2/97) isolates were positive for all AMEs tested genes. These results are inconsistent with the studies of Khosravi et al (2017) [43] and Goudarzi et al (2020) [44]. In agreement with our study, the ant(4')-la was the most prevalent gene in Yadegar et al (2009) [45]. As a result, according to other studies, the AMEs gene in the MRSA strains was higher than MSSA, which could be due to the ability of these strains to acquire resistance genetic elements.

In our study, isolates collected from blood and wound from patients hospitalized in ICU had the highest ability in biofilm formation. With this regard, $71.3 \%$ of the isolates were able to form biofilm, including strong (67.6\%), moderate (20.6\%) and weak (11.7\%). In MRSA isolates, $84.1 \%, 80.9 \%$ and $58.3 \%$ had a strong, moderate and weak phenotype, respectively. So, $84.1 \%, 19 \%$ and $41.6 \%$ of MSSA strains had strong, moderate and weak biofilm phenotype, respectively. These data are in contrast with Avila-Novoa et al (2018) [15] and Gowrishankar et al (2016) [28]. One reason for this discrepancy is source of the samples (food and pharyngitis samples vs our clinical samples). Contrary to our study, Ghasemian et al (2015) [27] declare that the prevalence of icaA, icaB, icaC and icaD were $73 \%(n=16), 63.6 \%(n=14), 73 \%(n=16)$ and $73 \%(n=16)$, respectively. So, they showed that there was no significant difference between MRSA and MSSA strains for the presence of icaADBC operon. In the present study, biofilm formation in MRSA isolates was far greater than MSSA. In line with Kord et al (2018) study, the highest and lowest ica gene was $i c a A$ and $i c a D$, respectively [46].

In our study, all MRSA isolates were harbored sea gene. The seb, sec and sed were detected in $17.5 \%, 5.2 \%$ and $3.1 \%$ of MRSA isolates. Sec and sed was not found in MSSA isolates. In a study performed by Mehrotra et al (2000) [22], among 107 strains collected from nasal swabs from healthy humans, 19.6\% $(n=21), 24.3 \%(n=26)$, $5.6 \%(n=6), 7.5 \%(n=8)$ and $1.9 \%(n=2)$ were positive for sea, tst, seb, sec, and sed, respectively. This contrast may be related to source of the sample (anterior nasal swabs vs clinic samples). Sabouni et al (2014) [47] showed that of $133 \mathrm{~S}$. aureus isolates $48 \%(n=64)$ were MRSA. The frequency of virulence-encoded genes was $40.6 \%, 19.6 \%, 12.8 \%, 11.3 \%, 9 \%, 4.5 \%$ and $3 \%$ for sea, seb, tsst, eta, etb, sed and sec, respectively. In contrast with the present study, among MSSA isolates, seb and tsst were the more prevalent toxins in comparison with MRSA isolates. In our samples, none of the MSSA isolates were positive for tsst-1 gene. Mir et al (2019) [16] showed that the frequency of $h l a, h l b, h / d, h l g$, $t s t$ and $p v /$ genes was $92.8 \%, 34.7 \%, 89.8 \%, 11.9 \%, 10.7 \%$, and $0.5 \%$ 
respectively. In line with our study, hla gene had the highest frequency among isolates $(94.4 \%$ for MRSA and $89.8 \%$ for MSSA). Exfoliative toxin A and B were detected in the $11.3 \%$ and $6.2 \%$ of MRSA isolates, respectively. In the MSSA strains, the etA gene was present in $4.3 \%$ and et $B$ in $6.5 \%$ of isolates. These data are similar to the results reported by Sila et al (2009) [48]. Also to support Sabouni et al (2014) study [47], et $A$ gene was higher among MRSA isolates. However, no significant relationship was observed in the presence of et $B$ between MRSA and MSSA strains. The et $A$ and $e t B$ genes are more common in samples collected from Skin and soft tissue lesions [47].

Bacterial adherent to target cell is the primary stage of infection. At this stage, attachment of $S$. aureus is facilitated by microbial surface component-recognizing adhesive matrix molecules (MSCRAMMs) including, $f n b A$ and $f n b B$ (encoding fibronectin-binding proteins $A$ and $B$ ), fib (encoding fibrinogen-binding proteins), cna (encoding collagen binding protein), $c l f A$ and $c / f B$ (encoding clumping factors $A$ and $B$ ), and eno (encoding laminin binding protein) [49]. The prevalence of the MSCRAMMs-encoding genes in the MRSA isolates was as follows: eno (84.5\%), fib (75.3\%), clfB (66\%), clfA (56.7\%), cna (52.3 \%), fnbA(15.5\%) and fnbB (13.4\%). These data are similar to Mir et al (2019) study [16]. As a result, the frequency of MSCRAMMs genes in MRSA strains was higher than in MSSA, which could be due to the high pathogenicity of the strains. The distribution of these genes in the samples collected from the ICU was much higher than the samples of other units. Also, the strains collected from the wound, sputum, blood, and BAL samples, had the highest frequency of these genes, respectively. Mir et al (2019) reported that various molecules such as collagen, fibrinogen, fibronectin and other factors are present in the burn wound [16]. S. aureus encodes many MSCRAMMs that precisely interact with host cells and it enables the microbe to colonize on the burn wounds. One of the most important virulence factors in $S$. aureus infections, particularly in skin and soft-tissue infections is the Panton-Valentine Leucocidin (PVL). This cytotoxin has been known as a virulence factor related to tissue necrosis such as necrotizing pneumonia (NP). MPCR showed that $6.3 \%(n=9 / 143)$ of $S$. aureus carried $p v /$ gene. In contrast with Mir et al (2019) [16] and Mkrtchyan et al (2017) [50] studies, 8\% of MRSA strains were positive for $p v /$ gene, all of which were CA-MRSA. In our isolates, $55.7 \%$ and $44.3 \%$ of mecA-positive strains were HA-MRSA and CA-MRSA, respectively. In various studies directed by Rodrigues et al (2013) [51] and Teare et al (2010) [52], the prevalence of $p v /$ gene was 14.6\% and $2 \%$ respectively. Surprisingly, in concordance with Mir et al (2019) [16] only one MSSA isolate (2.3\%) was positive for $p v l$ gene.

According to our result, the frequency rate of types I, II, III, IV, and V of SCCmec was $23.7 \%, 11.3 \%, 34 \%, 18.5 \%$ and $6.2 \%$, respectively. In line with Mariem et al (2013) [53] and Ghanbari et al (2016) [41], SCCmectyping did not show $100 \%$ type ability and had poor discriminatory power, as $6.4 \%$ of MRSA strains were nontypable. Overall, $75 \%(\mathrm{n}=6$ of 8 ) of $p v /$-positive MRSA strains belonged to the SCCmec type IV and V. In agreement with Taherirad et al (2016) [54], Ghanbari et al (2016) [41] and Moosavian et al (2017) [55], the most common SCCmec type was type III. However Jamshidi et al (2019) [56] and Boye et al (2007) [29] reported type IV as the most predominant type. This contrast may be related to the patients included in the study, multiple sclerosis (MS) cases vs various Staphylococcus infections and geographical locations.

\section{Conclusion}

We determined the high prevalence of virulence elements and raised rate of antimicrobial resistance in our samples. MRSA strains also have a high ability to form biofilm. In addition, SCCmec type III was recognized as 
the predominant type. These data recommend that efficient control procedures must to be considered to prevent the transmission of MRSA isolates among patients in hospital units especially in the ICU.

\section{Declarations}

\section{Acknowledgments}

We appreciate the sincere collaboration of the Microbiology Department, Ayatollah Amoli branch of Islamic Azad University and Department of Microbiology, School of Medicine, Babol University of Medical Sciences for assistance in the conduct of the study.

\section{Author Contributions}

HK and MTA conceived and designed the experiment; AP and MT conducted the study and collected the samples. AP, MT and FPG performed the experiments and analyzed the data. All authors contributed to paper writing. The authors have read and approved the final manuscript.

\section{Compliance with Ethical Standards}

\section{Funding}

This study was supported by the Ayatollah Amoli Branch, Islamic Azad University, Amol, Mazandaran province, Iran. The funding body had no role in the design of the study and collection, analysis, and interpretation of data and in writing the manuscript.

\section{Conflict of interest}

The authors declare that they have no conflicts of interest relevant to this study.

\section{Ethical Approval}

This study was approved by the Research Ethics Committee of Babol Branch, Islamic Azad University (approved ID: IR.IAU.BABOL.REC.1399.035) and performed in accordance with the Declaration of Helsinki. The participants signed the informed consent forms from each patient, and the Research Ethics Committee of Babol Branch, Islamic Azad University approved the study protocol.

\section{References}

1. Khandan Del A, Kaboosi H, Jamalli A, Peyravii Ghadikolaii F (2019) Prevalence and expression of psmA gene in biofilm-producing Staphylococcus aureus clinical isolates. Jundishapur J Microbiol 12(8):e89610. http://doi.org/10.5812/jjm.89610

2. Tong SYC, Davis JS, Eichenberger E, Holland TL, Fowler VGJr (2015) Staphylococcus aureus infections: epidemiology, pathophysiology, clinical manifestations, and management Clin Microbiol Rev 28(3): 603-661. http://doi.org/10.1128/CMR.00134-14

3. Antunes AL, Bonfanti JW, Perez LR, Pinto CC, Freitas AL, Macedo AJ, Barth AL (2011) High vancomycin resistance among biofilms produced by Staphylococcus species isolated from central venous catheters. 
Mem Inst Oswaldo Cruz 106(1):51-55. http://doi.org/10.1590/s0074-02762011000100008

4. Lade H, Park JH, Chung SH, Kim IH, Kim JM, Joo HS, Kim JS (2019) Biofilm formation by Staphylococcus aureus clinical isolates is differentially affected by glucose and sodium chloride supplemented culture media. J Clin Med 8(11):1853. https://doi.org/10.3390/jcm8111853

5. Gurung RR, Maharjan P, Chhetri GG (2020) Antibiotic resistance pattern of Staphylococcus aureus with reference to MRSA isolates from pediatric patients. Future Sci OA 6(4):FSO464. https://doi.org/10.2144/fsoa-2019-0122

6. IWG-SCC (2009) International Working Group on the Classification of Staphylococcal Cassette Chromosome Elements, Classification of Staphylococcal Cassette Chromosome mec (SCCmec): Guidelines for Reporting Novel SCCmec Elements. Antimicrob Agents Chemother 53(12):4961-4967. https://doi.org/10.1128/AAC.00579-09

7. Huang YH, Tseng SP, Hu JM, Tsai JC, Hsueh PR, Teng LJ (2007) Clonal spread of SCCmec type IV methicillinresistant Staphylococcus aureus between community and hospital. Clin Microbiol Infect 13(7):717-724. https://doi.org/10.1111/j.1469-0691.2007.01718.x

8. Desroches M, Potier J, Laurent F, Bourrel AS, Doucet-Populaire F, Decousser JW (2013) Prevalence of mupirocin resistance among invasive coagulase-negative staphylococci and methicillin-resistant Staphylococcus aureus (MRSA) in France: emergence of a mupirocin-resistant MRSA clone harbouring mupA. J Antimicrob Chemother 68(8):1714-1717. https://doi.org/10.1093/jac/dkt085

9. Sabzehali F, Goudarzi M, Goudarzi H, Azimi H (2017) Distribution of aminoglycoside resistance genes in coagulase-negative staphylococci isolated from hospitalized patients. Arch Pediatr Infect Dis 5(3):e57297. https://doi.org/10.5812/pedinfect.57297

10. Deotale V, Mendiratta DK, Raut U, Narang P (2010) Inducible clindamycin resistance in Staphylococcus aureus isolated from clinical samples. Indian J Med Microbiol 28(2):124-126. https://doi.org/10.4103/02550857.62488

11. Adhikari RP, Shrestha S, Barakoti A, Amatya R (2017) Inducible clindamycin and methicillin resistant Staphylococcus aureus in a tertiary care hospital, Kathmandu, Nepal. BMC Infect Dis 17(1):483. https://doi.org/10.1186/s12879-017-2584-5

12. Baron EG, Finegold SM (1999) Diagnostic Microbiology. $8^{\text {th }}$ ed, The CV Mosby Company, St. Louis

13. Patra KP, Vanchiere JA, Bocchini Jr JA (2011) Adherence to CLSI recommendations for testing of Staphylococcus aureus isolates in Louisiana hospitals: Report of a clinical failure and results of a questionnaire study. J Clin Microbiol 49(8):3019-3020. https://doi.org/10.1128/JCM.00944-11

14. Khodabandeh M, Mohammadi M, Abdolsalehi MR, Alvandimanesh A, Gholami M, Bibalan MH, Pournajaf A, Kafshgari R, Rajabnia R (2019) Analysis of resistance to macrolide-lincosamide-streptogramin B among mecA-positive Staphylococcus aureus isolates. Osong Public Health Res Perspect 10(1):25-31. https://doi.org/10.24171/j.phrp.2019.10.1.06

15. Avila-Novoa MG, Iñíguez-Moreno M, Solís-Velázquez OA, González-Gómez JP, Guerrero-Medina PJ, GutiérrezLomelí M (2018) Biofilm formation by Staphylococcus aureus isolated from food contact surfaces in the dairy industry of Jalisco, Mexico. J Food Quality 2018:1-8. https://doi.org/10.1155/2018/1746139

16. Mir Z, Nodeh Farahani N, Abbasian S, Alinejad F, Sattarzadeh M, Pouriran R, Dahmardehei M, Mirzaii M, Khoramrooz S, Darban-Sarokhalil D (2019) The prevalence of exotoxins, adhesion, and biofilm-related genes 
in Staphylococcus aureus isolates from the main burn center of Tehran, Iran. Iran J Basic Med Sci 22(11):1267-1274. https://doi.org/10.22038/ijbms.2019.34908.8291

17. Tristan A, Ying L, Bes M, Etienne J, Vandenesch F, Lina G (2003) Use of multiplex PCR to identify Staphylococcusaureus adhesins involved in human hematogenous infections. J Clin Microbiol 41(9):44654467. https://doi.org/10.1128/jcm.41.9.4465-4467.2003

18. Hoseini Alfatemi SM, Motamedifar M, Hadi N, Sedigh Ebrahim Saraie H (2014) Analysis of virulence genes among methicillin resistant Staphylococcus aureus (MRSA) strains. Jundishapur J Microbiol 7(6):e10741. https://doi.org/10.5812/jjm.10741

19. Nashev D, Toshkova K, Salasia SI, Hassan AA, Lämmler C, Zschöck M (2004) Distribution of virulence genes of Staphylococcus aureus isolated from stable nasal carriers. FEMS Microbiol Lett 233(1):45-52. https://doi.org/10.1016/j.femsle.2004.01.032

20. Yaghoubzadeh Z, Kaboosi H, Peyravii Ghadikolaii F, Safari R, Fattahi E (2020) The half maximal inhibitory concentration $\left(\mathrm{IC}_{50}\right)$ effect of protein hydrolysates from rainbow trout (Oncorhynchus mykiss) skin on enterotoxin a gene expression in Staphylococcus aureus. Int J Pept Res Ther 26:2411-2418. https://doi.org/10.1007/s10989-020-10036-4

21. Mahfoozi A, Shirzad-Aski H., Kaboosi H, Ghaemi EA (2019) Identification of the classical enterotoxin genes of Staphylococcus aureus in various foods by multiplex PCR assay. Iran J Vet Res 20(3):209-212

22. Mehrotra M, Wang G, Johnson WM (2000) Multiplex PCR for detection of genes for Staphylococcus aureus enterotoxins, exfoliative toxins, toxic shock syndrome toxin 1, and methicillin resistance. J Clin Microbiol 38(3):1032-1035. https://doi.org/10.1128/JCM.38.3.1032-1035.2000

23. Pournajaf A, Ardebili A, Goudarzi L, Khodabandeh M, Narimani T, Abbaszadeh H (2014) PCR-based identification of methicillin-resistant Staphylococcus aureus strains and their antibiotic resistance profiles. Asian Pac J Trop Biomed 4(Suppl 1):S293-S297. https://doi.org/10.12980/APJTB.4.2014C423

24. Gholami M, Haghshenas M, Moshiri M, Razavi S, Pournajaf A, Irajian G, Heidary M (2017) Frequency of 16S rRNA methylase and aminoglycoside-modifying enzyme genes among clinical isolates of Acinetobacter baumannii in Iran. Iran J Pathol 12(4):329-338

25. Choi SM, Kim SH, Kim HJ, Lee DG, Choi JH, Yoo JH, Kang JH, Shin WS, Kang MW (2003) Multiplex PCR for the detection of genes encoding aminoglycoside modifying enzymes and methicillin resistance among Staphylococcus species. J Korean Med Sci 18(5):631-636. https://doi.org/10.3346/jkms.2003.18.5.631

26. Shekarabi M, Hajikhani B, Salimi Chirani A, Fazeli M, Goudarzi M (2017) Molecular characterization of vancomycin-resistant Staphylococcus aureus strains isolated from clinical samples: A three year study in Tehran, Iran. PLoS One 12(8):e0183607. https://doi.org/10.1371/journal.pone.0183607

27. Ghasemian A, Najar-Peerayeh S, Bakhshi B, Mirzaee M (2015) High prevalence of icaABCD genes responsible for biofilm formation in clinical isolates of Staphylococcus aureus from hospitalized children. Arch Pediatr Infect Dis 3(3):e20703. https://doi.org/10.5812/pedinfect.20703v2

28. Gowrishankar S, Kamaladevi A, Balamurugan K, Pandian SK (2016) In vitro and in vivo biofilm characterization of methicillin-resistant Staphylococcus aureus from patients associated with pharyngitis infection. Biomed Res Int 2016:1-14. https://doi.org/10.1155/2016/1289157

29. Boye K, Bartels MD, Andersen IS, Møller JA, Westh H (2007) A new multiplex PCR for easy screening of methicillin-resistant Staphylococcus aureus SCCmec types I-V. Clin Microbiol Infect 13(7):725-727. https://doi.org/10.1111/j.1469-0691.2007.01720.x

Page 13/20 
30. Darban-Sarokhalil D, Khoramrooz SS, Marashifard M, Malek Hosseini SA, Parhizgari N, Yazdanpanah M, Gharibpour F, Mirzaii M, Sharifi B, Haeili M (2016) Molecular characterization of Staphylococcus aureus isolates from southwest of Iran using spa and SCCmectyping methods. Microb Pathog 98:88-92. https://doi.org/10.1016/j.micpath.2016.07.003

31. Kateete DP, Namazzi S, Okee M, Okeng A, Baluku H, Musisi NL, Katabazi FA, Joloba M.L, Ssentongo R, Najjuka FC (2011) High prevalence of methicillin resistant Staphylococcus aureus in the surgical units of Mulago hospital in Kampala, Uganda. BMC Res Notes 4:326. https://doi.org/10.1186/1756-0500-4-326

32. Guardabassi L, Stegger M, Skov R (2007) Retrospective detection of methicillin resistant and susceptible Staphylococcus aureus ST398 in Danish slaughter pigs. Vet Microbiol 122(3-4):384-386.

https://doi.org/10.1016/j.vetmic.2007.03.021

33. Solgi S, Razavi S, Nateghian A, Irajian G, Pournajaf A, Hasannejad-Bibalan M, Rahmani S (2019) Resistancerelated determinants in clinically relevant Staphylococcus aureus isolated from teaching therapeutic centers, Tehran, Iran. Rev Med Microbiol 30(3):142-147. https://doi.org/10.1097/MRM.0000000000000173

34. Chaturvedi P, Singh AK, Singh AK, Shukla S, Agarwal L (2014) Prevalence of mupirocin resistant Staphylococcus aureus isolates among patients admitted to a tertiary care hospital. N Am J Med Sci 6(8):403-407. https://doi.org/10.4103/1947-2714.139293

35. Antonov NK, Garzon MC, Morel KD, Whittier S, Planet PJ, Lauren CT (2015) High prevalence of mupirocin resistance in Staphylococcus aureus isolates from a pediatric population. Antimicrob Agents Chemother 59(6):3350-3356. https://doi.org/10.1128/AAC.00079-15

36. McNeil JC, Hulten KG, Kaplan SL, Mason EO (2011) Mupirocin resistance in Staphylococcus aureus causing recurrent skin and soft tissue infections in children. Antimicrob Agents Chemother 55(5):2431-2433. https://doi.org/10.1128/AAC.01587-10

37. Chen X, Yang HH, Huangfu YC, Wang WK, Liu Y, Ni YX, Han LZ (2012) Molecular epidemiologic analysis of Staphylococcus aureus isolated from four burn centers. Burns 38(5):738-742.

https://doi.org/10.1016/j.burns.2011.12.023

38. Gupta V, Datta P, Rani H, Chander J (2009) Inducible clindamycin resistance in Staphylococcus aureus: a study from North India. J Postgrad Med 55(3):176-179. https://doi.org/10.4103/0022-3859.57393

39. Seifi N, Kahani N, Askari E, Mahdipour S, Naderi NM (2012) Inducible clindamycin resistance in Staphylococcus aureus isolates recovered from Mashhad, Iran. Iran J Microbiol 4(2):82-86

40. Ruiz-Ripa L, Alcalá L, Simón C, Gómez P, Mama OM, Rezusta A, Zarazaga M, Torres C (2019) Diversity of Staphylococcus aureus clones in wild mammals in Aragon, Spain, with detection of MRSA ST130-mecC in wild rabbits. J Appl Microbiol 127(1):284-291. https://doi.org/10.1111/jam.14301

41. Ghanbari F, Ghajavand H, Havaei R, Jami MS, Khademi F, Heydari L, Shahin M, Havaei SA (2016) Distribution of erm genes among Staphylococcus aureus isolates with inducible resistance to clindamycin in Isfahan, Iran. Adv Biomed Res 5(62). https://doi.org/10.4103/2277-9175.179184

42. Saribas Z, Tunckanat F, Pinar A (2006) Prevalence of erm genes encoding macrolide-lincosamidestreptogramin (MLS) resistance among clinical isolates of Staphylococcus aureus in a Turkish university hospital. Clin Microbiol Infect 12(8):797-799. https://doi.org/10.1111/j.1469-0691.2006.01486.x

43. Khosravi AD, Jenabi A, Montazeri EA (2017) Distribution of genes encoding resistance to aminoglycoside modifying enzymes in methicillin-resistant Staphylococcus aureus (MRSA) strains. Kaohsiung J Med Sci 33(12):587-593. https://doi.org/10.1016/j.kjms.2017.08.001

Page $14 / 20$ 
44. Goudarzi M, Tayebi Z, Dadashi M, Miri M, Amirpour A, Fazeli M (2020) Characteristics of communityacquired methicillin-resistant Staphylococcus aureus associated with wound infections in Tehran, Iran: High prevalence of PVL+ t008 and the emergence of new spa types t657, t5348, and t437 in Iran. Gene Rep 19:100603. https://doi.org/10.1016/j.genrep.2020.100603

45. Yadegar A, Sattari M, Mozafari NA, Goudarzi GR (2009) Prevalence of the genes encoding aminoglycosidemodifying enzymes and methicillin resistance among clinical isolates of Staphylococcus aureus in Tehran, Iran. Microb Drug Resist 15(2):109-13. https://doi.org/10.1089/mdr.2009.0897

46. Kord M, Ardebili A, Jamalan M, Jahanbakhsh R, Behnampour N, Ghaemi EA (2018) Evaluation of biofilm formation and presence of ica genes in Staphylococcus epidermidis clinical isolates. Osong Public Health Res Perspect 9(4):160-166. https://doi.org/10.24171/j.phrp.2018.9.4.04

47. Sabouni F, Mahmoudi S, Bahador A, Pourakbari B, Sadeghi RH, Ashtiani MT, Nikmanesh B, Mamishi S (2014) Virulence factors of Staphylococcus aureus isolates in an Iranian referral children's hospital. Osong Public Health Res Perspect 5(2):96-100. https://doi.org/10.1016/j.phrp.2014.03.002

48. Sila J, Sauer P, Kolar M (2009) Comparison of the prevalence of genes coding for enterotoxins, exfoliatins, panton-valentine leukocidin and tsst-1 between methicillin-resistant and methicillin-susceptible isolates of Staphylococcus aureus at the university hospital in Olomouc. Biomed Pap Med Fac Univ Palacky Olomouc Czech Repub 153(3):215-218. https://doi.org/10.5507/bp.2009.036

49. Archer NK, Mazaitis MJ, Costerton JW, Leid JG, Powers ME, Shirtliff ME (2011) Staphylococcus aureus biofilms: properties, regulation, and roles in human disease. Virulence 2(5):445-459. https://doi.org/10.4161/viru.2.5.17724

50. Mkrtchyan HV, Xu Z, Yacoub M, Ter-Stepanyan MM, Karapetyan HD, Kearns AM, Cutler RR, Pichon B, Hambardzumyan AD (2017) Detection of diverse genotypes of Methicillin-resistant Staphylococcus aureus from hospital personnel and the environment in Armenia. Antimicrob Resist Infect Control 6(19). https://doi.org/10.1186/s13756-017-0169-0

51. Rodrigues MV, Fortaleza CM, Riboli DF, Rocha RS, Rocha C, da Cunha MdeL (2013) Molecular epidemiology of methicillin-resistant Staphylococcus aureus in a burn unit from Brazil. Burns 39(6):1242-1249. https://doi.org/10.1016/j.burns.2013.02.006

52. Teare L, Shelley OP, Millership S, Kearns A (2010) Outbreak of Panton-Valentine leucocidin-positive meticillinresistant Staphylococcus aureus in a regional burns unit. J Hosp Infect 76(3):220-224.

https://doi.org/10.1016/j.jhin.2010.04.023

53. Mariem BJ, Ito T, Zhang M, Jin J, Li S, Ilhem BB, Adnan H, Han X, Hiramatsu K (2013) Molecular characterization of methicillin-resistant Panton-valentine leukocidin positive staphylococcus aureus clones disseminating in Tunisian hospitals and in the community. BMC Microbiol 13(2). https://doi.org/10.1186/1471-2180-13-2

54. Taherirad A, Jahanbakhsh R, Shakeri F, Anvary S, Ghaemi EA (2016) Staphylococcal cassette chromosome mec types among methicillin-resistant Staphylococcus aureus in northern Iran. Jundishapur J Microbiol 9(8):e33933. https://doi.org/10.5812/jjm.33933

55. Moosavian M, Shahin M, Navidifar T, Torabipour M (2017) Typing of staphylococcal cassette chromosome mec encoding methicillin resistance in Staphylococcus aureus isolates in Ahvaz, Iran. New Microbes New Infect 21:90-94. https://doi.org/10.1016/j.nmni.2017.11.006 
56. Jamshidi Y, Pourmand MR, Pakbaz Z, Pourmand A, Rahimi Foroushani A, Sahraian MA (2019) SCCmec genotypes of methicillin-resistant Staphylococcus aureus in nasal carriage of multiple sclerosis patients in Iran. Iran J Public Health 48(12):2270-2276

\section{Tables 1 And 2}

Table 1 Oligonucleotide primer sequences used in this study 


\begin{tabular}{|c|c|c|c|c|c|}
\hline Gene type & Encoded protein & Target Gene & Primer sequences $(5 \square \rightarrow 3 \square)$ & $\begin{array}{l}\text { Amplicon } \\
\text { size (bp) }\end{array}$ & References \\
\hline \multirow[t]{19}{*}{$\begin{array}{l}\text { Virulence } \\
\text { association } \\
\text { genes }\end{array}$} & $\begin{array}{l}\text { Collagen- } \\
\text { Binding } \\
\text { Protein }\end{array}$ & can & $\begin{array}{l}\mathrm{F}=5 \square-G T C A A G C A G T T A T T A A C A C C A G A C-3 \square \\
\mathrm{R}=5 \square-A A T C A G T A A T T G C A C T T T G T C C A C T G-\end{array}$ & 423 & {$[16]$} \\
\hline & \multirow[t]{2}{*}{$\begin{array}{l}\text { Clumping } \\
\text { Factors A/B }\end{array}$} & clfA & $\begin{array}{c}\mathrm{F}=5 \square-\text { ATTGGCGTGGCTTCAGTGCT-3ロ } \\
\mathrm{R}=5 \square-\text { CGTTTCTTCCGTAGTTGCATTTG-3ロ }\end{array}$ & 292 & \multirow[t]{4}{*}{ [17] } \\
\hline & & clfB & $\begin{array}{c}\mathrm{F}=5 \square-\text { ACATCAGTAATAGTAGGGGGCAAC-3ם } \\
\mathrm{R}=5 \square-\text { TTCGCACTGTTTGTGTTTGCAC-3ロ }\end{array}$ & 205 & \\
\hline & \multirow[t]{2}{*}{$\begin{array}{l}\text { Fibronectin- } \\
\text { Binding } \\
\text { Proteins A/B }\end{array}$} & $f n b A$ & $\begin{array}{c}\mathrm{F}=5 \square- \\
\text { GTGAAGTTTTAGAAGGTGGAAAGATTAG-3ם } \\
\text { R=5ロ- GCTCTTGTAAGACCATTTTTCTTCAC- }\end{array}$ & 643 & \\
\hline & & $f n b B$ & $\begin{array}{c}\mathrm{F}=5 \square- \\
\text { GTAACAGCTAATGGTCGAATTGATACT-3ם } \\
\mathrm{R}=5 \square-\text { CAAGTTCGATAGGAGTACTATGTTC-3ם }\end{array}$ & 524 & \\
\hline & $\begin{array}{l}\text { Fibrinogen- } \\
\text { Binding Protein }\end{array}$ & fib & $\begin{array}{l}\mathrm{F}=5 \square-C T A C A A C T A C A A T T G C C G T C A A C A G-3 \square \\
\mathrm{R}=5 \square-G C T C T T G T A A G A C C A T T T T C T T C A C-3 \square\end{array}$ & 404 & \multirow[t]{2}{*}[16]{} \\
\hline & $\begin{array}{c}\text { Laminin- } \\
\text { Binding Protein }\end{array}$ & eno & $\begin{array}{c}\mathrm{F}=5 \square-\text { ACGTGCAGCAGCTGACT-3ロ } \\
\mathrm{R}=5 \square-C A A C A G C A T Y C T T C A G T A C C T T C-3 \square\end{array}$ & 302 & \\
\hline & \multirow[t]{4}{*}{$\begin{array}{l}\text { Hemolysin- } \\
\text { encoding } \\
\text { genes }\end{array}$} & hla & $\begin{array}{c}\mathrm{F}=5 \square- \\
\text { CTGATTACTATCCAAGAAATTCGATTG-3ם } \\
\mathrm{R}=5 \square-C T T T C C A G C C T A C T T T T T T A T C A G T-3 \square\end{array}$ & 209 & [18] \\
\hline & & hlb & $\begin{array}{c}\mathrm{F}=5 \square-\text { GTGCACTTACTGACAATAGTGC-3ロ } \\
\mathrm{R}=5 \square-\text { GTTGATGAGTAGCTACCTTCAGT-3ロ }\end{array}$ & 309 & [16] \\
\hline & & hld & $\begin{array}{c}\mathrm{F}=5 \square- \\
\text { AAGAATTTTTATCTTAATTAAGGAAGGAGTG- } \\
3 \square \\
\mathrm{R}=5 \square-\text { TTAGTGAATTTGTTCACTGTGTCGA } \\
-3 \square\end{array}$ & 111 & [18] \\
\hline & & hlg & $\begin{array}{c}\mathrm{F}=5 \square-\text { GCCAATCCGTTATTAGAAAATGC-3ロ } \\
\mathrm{R}=5^{\prime}-\mathrm{CCATAGACGTAGCAACGGAT}-3^{\prime}\end{array}$ & 937 & [16] \\
\hline & $\begin{array}{l}\text { Toxic Shock } \\
\text { Syndrome } \\
\text { Toxin-1 }\end{array}$ & tsst-1 & $\begin{array}{c}\mathrm{F}=5 \square-\text { ATGGCAGCATCAGCTTGATATTT-3ロ } \\
\text { R=5ロ- CCAATAACCACCCGTTT-3ロ }\end{array}$ & 350 & [18] \\
\hline & $\begin{array}{l}\text { Panton- } \\
\text { Valentine } \\
\text { Leukocidin }\end{array}$ & $p v l$ & $\begin{array}{c}\mathrm{F}=5 \square- \\
\text { ATCATTAGGTAAAATGTCTGGACATGATCCA- } \\
3 \square \\
\mathrm{R}=5 \square-G C A T C A A S T G T A T T G G A T A G C A A A A G C-\end{array}$ & 433 & [16] \\
\hline & \multirow{4}{*}{$\begin{array}{l}\text { Staphylococcal } \\
\text { Enterotoxin } \\
\text { A/B/C/D }\end{array}$} & sea & $\begin{array}{c}\mathrm{F}=5 \square-\mathrm{TTGCGAAAAAAGTCTGAATTGC-3 \square} \\
\mathrm{R}=5 \square-\text { ATTAACCGAAGGTTCTGTAGAAGTA-3ם }\end{array}$ & 552 & {$[20]$} \\
\hline & & seb & $\begin{array}{l}\mathrm{F}=5 \square-\text { GTATGGTGGTGTAACTGAGC-3ロ } \\
\mathrm{R}=5 \square-\text { CCAAATAGTGACGAGTTAGG -3ロ }\end{array}$ & 164 & [21] \\
\hline & & sec & $\begin{array}{l}\mathrm{F}=5 \square-\text { GACATAAAAGCTAGGAATTT-3ロ } \\
\mathrm{R}=5 \square-\text { AAATCGGATTAACATTATCC-3ロ }\end{array}$ & 257 & {$[21]$} \\
\hline & & sed & $\begin{array}{l}\mathrm{F}=5 \square-\text { CTAGTTTGGTAATATCTCCT-3ロ } \\
\mathrm{R}=5 \square-\text { TAATGCTATATCTTATAGGG-3ロ }\end{array}$ & 317 & \\
\hline & \multirow[t]{2}{*}{$\begin{array}{l}\text { Exfoliative } \\
\text { Toxin A/B }\end{array}$} & eta & $\begin{array}{l}\mathrm{F}=5 \square-\text { GCAGGTGTTGATTTAGCATT-3ロ } \\
\mathrm{R}=5 \square-\text { AGATGTCCCTATTTTTGCTG-3ם }\end{array}$ & 93 & \multirow[t]{2}{*}[22]{} \\
\hline & & etb & $\begin{array}{l}\mathrm{F}=5 \square-\text { ACAAGCAAAAGAATACAGCG-3ロ } \\
\mathrm{R}=5 \square-\text { GTTTTTGGCTGCTTCTCTTG-3ם }\end{array}$ & 226 & \\
\hline \multirow{2}{*}{$\begin{array}{l}\text { Resistance } \\
\text { encoding } \\
\text { genes }\end{array}$} & $\begin{array}{l}\text { Resistance to } \\
\text { Methicillin }\end{array}$ & $m e c A$ & $\begin{array}{l}\mathrm{F}=5 \square-A A A A T C G A T G G T A A A G G T T G G C-3 \square \\
\mathrm{R}=5 \square-A G T T C T G G A G T A C C G G A T T T G C-3 \square\end{array}$ & 533 & \multirow[t]{2}{*}{ [23] } \\
\hline & $\begin{array}{l}\text { Resistance to } \\
\text { Mupirocin }\end{array}$ & ileS-2 (mupA) & $\begin{array}{c}F=5 \square-T A T A T T A T G C G A T G G A A G G T T G G-3 \square \\
R=5 \square-\text { AATAAAATCAGCTGGAAAGTGTTG-3ロ }\end{array}$ & 456 & \\
\hline
\end{tabular}

Page 17/20 


\begin{tabular}{|c|c|c|c|c|c|}
\hline & \multirow{4}{*}{$\begin{array}{l}\text { Aminoglycoside- } \\
\text { enzymes } \\
\text { modifying }\end{array}$} & $A P H\left(3^{\prime}\right)-I$ & $\begin{array}{l}\mathrm{F}=5 \square-\text { ATGTGCCATATTCAACGGGAAACG-3ロ } \\
\mathrm{R}=5 \square-\mathrm{TCAGAAAAACTCATCGAGCATCAA-3 \square}\end{array}$ & 816 & \multirow[t]{2}{*}{ [24] } \\
\hline & & $A P H\left(3^{\prime}\right)$-IIIa & 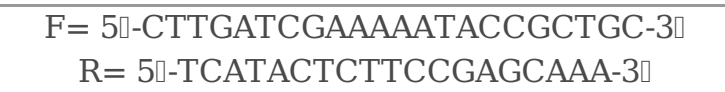 & 296 & \\
\hline & & $\begin{array}{c}\operatorname{aac}\left(6^{\prime}\right) / \operatorname{aph}\left(2^{\prime}\right. \\
\prime)\end{array}$ & 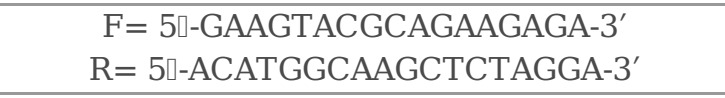 & 491 & [25] \\
\hline & & $A N T\left(4^{\prime}\right)-I a$ & $\begin{array}{c}\mathrm{F}=5 \square-A A T C G G T A G A A G C C C A A-3 \square \\
\mathrm{R}=5 \square-G C A C C T G C C A T T G C T A-3 \square\end{array}$ & 135 & [26] \\
\hline & $\begin{array}{l}\text { Resistance to } \\
\text { Vancomycin }\end{array}$ & $\operatorname{van} A$ & 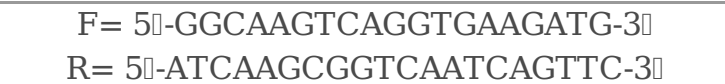 & 713 & \\
\hline & $\begin{array}{l}\text { Inducible } \\
\text { Resistance }\end{array}$ & erm $A$ & $\begin{array}{l}\mathrm{F}=5^{\prime} \text {-TATCTTATCGTTGAGAAGGGATT-3' } \\
\mathrm{R}=5^{\prime} \text {-CTACACTTGGCTTAGGATGAAA-3' }\end{array}$ & 139 & [14] \\
\hline & & ermB & $\begin{array}{c}\mathrm{F}=5 \square- \\
\text { CCGTTTACGAAATTGGAACAGGTAAAGGGC- } \\
3 \square \\
\mathrm{R}=5 \square-G A A T C G A G A C T T G A G T G T G C-3 \square\end{array}$ & 359 & \\
\hline & & ermC & $\begin{array}{l}\mathrm{F}=5^{\prime}-\text { ATCTTTGAAATCGGCTCAGG -3' } \\
\mathrm{R}=5^{\prime}-\text { CAAACCCGTATTCCACGATT }-3^{\prime}\end{array}$ & 295 & \\
\hline & & ere $A$ & $\begin{array}{l}\mathrm{F}=5^{\prime}-\text { AACACCCTGAACCCAAGGGACG-3' } \\
\mathrm{R}=5^{\prime}-\text { CTTCACATCCGGATTCGCTCGA-3' }\end{array}$ & 420 & \\
\hline \multirow[t]{4}{*}{$\begin{array}{l}\text { biofilm- } \\
\text { genes }\end{array}$} & \multirow[t]{4}{*}{$\begin{array}{l}\text { Biofilm- } \\
\text { encoding genes }\end{array}$} & icaA & $\begin{array}{l}\mathrm{F}=5 \square-G A T T A T G T A A T G T G C T T G G A-3 \square \\
\mathrm{R}=5^{\prime}-\text { ACTACTGCTGCGTTAATAAT-3' }\end{array}$ & 770 & [27] \\
\hline & & $i c a B$ & $\begin{array}{c}\mathrm{F}=5 \square-\text { AGAATCGTGAAGTATAGAAAATT }-3^{\prime} \\
\mathrm{R}=5 \square-\text { TCTAATCTTTTTCATGGAATCCGT }-3^{\prime}\end{array}$ & 900 & [28] \\
\hline & & icaC & $\begin{array}{c}\mathrm{F}=5 \square-C A T G A A A A T A T G G A G G G T G G-3^{\prime} \\
\mathrm{R}=5 \square-\text { TCAAACTGATTTCGCCCACCG-3' }\end{array}$ & 1000 & [28] \\
\hline & & $i c a D$ & $\begin{array}{c}\mathrm{F}=5 \square-A A A C G T A A G A G A G G T G G-3 \square \\
\mathrm{R}=5 \square-G G C A A T A T G A T C A A G A T A C-3 \square\end{array}$ & 381 & [16] \\
\hline \multirow[t]{4}{*}{$\begin{array}{c}\text { SCC mec } \\
\text { typing }\end{array}$} & Type II \&IV & CCrA2-B & $\begin{array}{c}\mathrm{F}=5 \square-A T T G C C T T G A T A A T A G C C Y T C T-3 \square \\
\mathrm{R}=5 \square-T A A A G G C A T C A A T G C A C A A A C A C T-3 \square\end{array}$ & 937 & \multirow[t]{4}{*}{ [29] } \\
\hline & Type III \& V & $C C r$ & $\begin{array}{c}\mathrm{F}=\text { 5ロ-CGTCTATTACAAGATGTTAAGGATAAT- } \\
3 \square \\
\mathrm{R}=5 \square- \\
\text { CATTTATAGACTGGATTATTCAAAATAT-3ם }\end{array}$ & 518 & \\
\hline & Type I \& IV & IS1272 & $\begin{array}{c}\mathrm{F}=5 \square-G C C A C T C A T A A C A T A T G G A A-3 \square \\
\mathrm{R}=5 \square-C A T C C G A G T G A A A C C C A A A-3 \square\end{array}$ & 415 & \\
\hline & Type V & mecA-IS431 & $\begin{array}{l}\mathrm{F}=5 \square-T A T A C C A A A C C C G A C A A C T A C-3 \square \\
\mathrm{R}=5 \square-C G G C T A C A G T G A T A A C A T C C-3 \square\end{array}$ & 359 & \\
\hline
\end{tabular}

Table 2 M-PCRs conditions and cycles in the present study 


\begin{tabular}{|c|c|c|c|c|}
\hline $\begin{array}{c}\text { Reaction } \\
\text { set }\end{array}$ & Amplified genes & Reaction compounds & M-PCR program & $\begin{array}{c}\text { Cycles of } \\
\text { amplification }\end{array}$ \\
\hline S1 & $\begin{array}{c}\text { Cna/clfA/ fnbA/ } \\
\text { fnbB/tsst-1 }\end{array}$ & $\begin{array}{l}1.0 \mu \mathrm{L} \text { of template DNA, } \\
12.1 \mu \mathrm{L} \text { of CinnaGen PCR } \\
\text { Master Mix, } 0.8 \mu \mathrm{L} \text { of } \\
\text { each primer, and } 10.3 \mu \mathrm{L} \\
\text { of ddH2O. }\end{array}$ & $\begin{array}{c}\text { initial denaturation at } 94^{\circ} \mathrm{C} \text { for } 5 \mathrm{~min} \text {, } \\
\text { denaturation at } 95^{\circ} \mathrm{C} \text { for } 30 \mathrm{~s} \text {, annealing } \\
\text { at } 56^{\circ} \mathrm{C} \text { for } 60 \mathrm{~s} \text {, extension at } 72^{\circ} \mathrm{C} \text { for } \\
60 \mathrm{~s} \text { and a final extension at } 72^{\circ} \mathrm{C} \text { for } 5 \\
\text { min. }\end{array}$ & \multirow[t]{2}{*}{30} \\
\hline S2 & clfB/fib/eno/mecA & \multirow[t]{2}{*}{$\begin{array}{l}0.9 \mu \mathrm{L} \text { of template DNA, } \\
\text { 10.6 } \mu \mathrm{L} \text { of CinnaGen PCR } \\
\text { Master Mix, } 1.0 \mu \mathrm{L} \text { of } \\
\text { each primer, and } 11.5 \mu \mathrm{L} \\
\text { of ddH2O }\end{array}$} & $\begin{array}{c}\text { initial denaturation at } 95^{\circ} \mathrm{C} \text { for } 5 \mathrm{~min} \text {, } \\
\text { denaturation at } 94^{\circ} \mathrm{C} \text { for } 45 \mathrm{~s} \text {, annealing } \\
\text { at } 55^{\circ} \mathrm{C} \text { for } 50 \mathrm{~s} \text {, extension at } 72^{\circ} \mathrm{C} \text { for } \\
60 \mathrm{~s} \text { and a final extension at } 72^{\circ} \mathrm{C} \text { for } 6 \\
\text { min. }\end{array}$ & \\
\hline S3 & hla/hlb/hld/hlg/pvl & & $\begin{array}{c}\text { initial denaturation at } 96^{\circ} \mathrm{C} \text { for } 6 \text { min, } \\
\text { denaturation at } 95^{\circ} \mathrm{C} \text { for } 50 \mathrm{~s} \text {, annealing } \\
\text { at } 57^{\circ} \mathrm{C} \text { for } 45 \mathrm{~s} \text {, extension at } 72^{\circ} \mathrm{C} \text { for } \\
60 \mathrm{~s} \text { and a final extension at } 72^{\circ} \mathrm{C} \text { for } 5 \\
\text { min. }\end{array}$ & 32 \\
\hline S4 & $\begin{array}{c}\text { Sea/seb/sec/sed/ ileS- } \\
2\end{array}$ & \multirow[t]{2}{*}{$\begin{array}{l}0.8 \mu \mathrm{L} \text { of template DNA, } \\
\text { 11.6 } \mu \mathrm{L} \text { of CinnaGen PCR } \\
\text { Master Mix, } 1.0 \mu \mathrm{L} \text { of } \\
\text { each primer, and } 10.6 \mu \mathrm{L} \\
\text { of ddH2O. }\end{array}$} & $\begin{array}{c}\text { initial denaturation at } 95^{\circ} \mathrm{C} \text { for } 5 \mathrm{~min} \text {, } \\
\text { denaturation at } 95^{\circ} \mathrm{C} \text { for } 55 \mathrm{~s} \text {, annealing } \\
\text { at } 56^{\circ} \mathrm{C} \text { for } 45 \mathrm{~s} \text {, extension at } 72^{\circ} \mathrm{C} \text { for } \\
60 \mathrm{~s} \text { and a final extension at } 72^{\circ} \mathrm{C} \text { for } 5 \\
\text { min. }\end{array}$ & 35 \\
\hline S5 & eta/etb & & $\begin{array}{c}\text { initial denaturation at } 95^{\circ} \mathrm{C} \text { for } 7 \mathrm{~min} \text {, } \\
\text { denaturation at } 94^{\circ} \mathrm{C} \text { for } 45 \mathrm{~s} \text {, annealing } \\
\text { at } 55^{\circ} \mathrm{C} \text { for } 40 \mathrm{~s} \text {, extension at } 72^{\circ} \mathrm{C} \text { for } \\
50 \mathrm{~s} \text { and a final extension at } 72^{\circ} \mathrm{C} \text { for } 7 \\
\text { min. }\end{array}$ & 31 \\
\hline S6 & 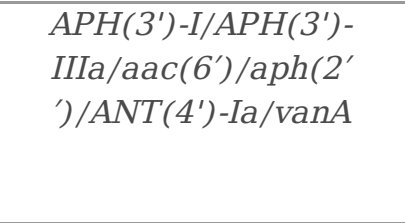 & $\begin{array}{l}1.0 \mu \mathrm{L} \text { of template DNA, } \\
12.5 \mu \mathrm{L} \text { of CinnaGen PCR } \\
\text { Master Mix, } 1.0 \mu \mathrm{L} \text { of } \\
\text { each primer, and } 9.5 \mu \mathrm{L} \\
\text { of ddH2O. }\end{array}$ & $\begin{array}{c}\text { initial denaturation at } 95^{\circ} \mathrm{C} \text { for } 6 \mathrm{~min} \text {, } \\
\text { denaturation at } 95^{\circ} \mathrm{C} \text { for } 50 \mathrm{~s} \text {, annealing } \\
\text { at } 53^{\circ} \mathrm{C} \text { for } 45 \mathrm{~s} \text {, extension at } 72^{\circ} \mathrm{C} \text { for } \\
50 \mathrm{~s} \text { and a final extension at } 72^{\circ} \mathrm{C} \text { for } 10 \\
\text { min. }\end{array}$ & 30 \\
\hline S7 & ermA/ermB/ermC/ere $A$ & $\begin{array}{l}1.0 \mu \mathrm{L} \text { of template DNA, } \\
12.3 \mu \mathrm{L} \text { of CinnaGen PCR } \\
\text { Master Mix, } 0.9 \mu \mathrm{L} \text { of } \\
\text { each primer, and } 9.9 \mu \mathrm{L} \\
\text { of ddH2O. }\end{array}$ & \multirow[t]{2}{*}{$\begin{array}{c}\text { initial denaturation at } 95^{\circ} \mathrm{C} \text { for } 6 \text { min, } \\
\text { denaturation at } 94^{\circ} \mathrm{C} \text { for } 55 \mathrm{~s} \text {, annealing } \\
\text { at } 57^{\circ} \mathrm{C} \text { for } 50 \mathrm{~s} \text {, extension at } 72^{\circ} \mathrm{C} \text { for } \\
60 \mathrm{~s} \text { and a final extension at } 72^{\circ} \mathrm{C} \text { for } 5 \\
\text { min. }\end{array}$} & 35 \\
\hline S8 & IcaA/icaB/icaC/icaD & $\begin{array}{l}0.8 \mu \mathrm{L} \text { of template DNA, } \\
11.7 \mu \mathrm{L} \text { of CinnaGen PCR } \\
\text { Master Mix, } 0.9 \mu \mathrm{L} \text { of } \\
\text { each primer, and } 10.7 \mu \mathrm{L} \\
\text { of ddH2O. }\end{array}$ & & 33 \\
\hline S9 & $\begin{array}{c}\text { ccrA2- } \\
B / \text { ccr/IS1272/mecA- } \\
\text { IS431 }\end{array}$ & $\begin{array}{l}0.9 \mu \mathrm{L} \text { of template DNA, } \\
12.2 \mu \mathrm{L} \text { of CinnaGen PCR } \\
\text { Master Mix, } 0.8 \mu \mathrm{L} \text { of } \\
\text { each primer, and } 10.3 \mu \mathrm{L} \\
\text { of ddH2O. }\end{array}$ & $\begin{array}{c}\text { initial denaturation at } 94^{\circ} \mathrm{C} \text { for } 5 \mathrm{~min} \text {, } \\
\text { denaturation at } 95^{\circ} \mathrm{C} \text { for } 45 \mathrm{~s} \text {, annealing } \\
\text { at } 55^{\circ} \mathrm{C} \text { for } 60 \mathrm{~s} \text {, extension at } 72^{\circ} \mathrm{C} \text { for } \\
60 \mathrm{~s} \text { and a final extension at } 72^{\circ} \mathrm{C} \text { for } 10 \\
\text { min. }\end{array}$ & 32 \\
\hline
\end{tabular}

\section{Supplementary Files}


This is a list of supplementary files associated with this preprint. Click to download.

- Footnotes.doc 